\title{
Family Formation, Gender and Labor Force Participation Decision in Developing Countries
}

\author{
Babar Aziz ${ }^{1}$, Zahid Iqbal'2, Muhammad Usman ${ }^{3}$ and Komal Abbas ${ }^{4}$
}

\begin{abstract}
The study aims to explore the effect offamily ties, age, education and gender on the employment status of individuals in developing countries. To examine the relationship between strong facility ties and economic activities, data of sixty developing economies have been extracted from World Value Survey (WVS). Principle Component Analysis (PCA) and Factor Analysis (FA) are applied to construct the index of family ties. The study reveals that the influence of strong family ties on economic behavior is much obvious in the case of females in lowincome countries. The results also describe that females as compared to males are less encouraged to work and move outside the home to participate in economic activities. Moreover, the age of individuals has a negative effect on employment status, while education illustrates a positive relationship. Thus, the findings suggest that in developing countries, females may show their preferences for joining the labor market in the presence of stronger family ties. More importantly, females and the young labor force are major chunks of the labor force in the demographic structure of the developing countries, so the contribution of females will have a positive effect on the economy and thus strong family ties may play a vital role in the progress of the developing countries.
\end{abstract}

Keywords: Demographic Structure, Family Ties, Gender, Age and Education, Labor Force Participation

JEL Classification: J10, D19, I25, E24

\section{Introduction}

The concept of family economics has moved ahead from birth rates, death rates, marriages and divorces to the socioeconomic factors, which might influence the family cohesion. Family, being society's most fundamental institution, plays an important role in the decision making of an individual. Ample literature is available on family economics but a large part of literature consists of theoretical aspects and very few studies highlight the influence of family ties on economic development.

\footnotetext{
${ }^{1}$ Professor, Department of Economics, Government College University, Lahore, Pakistan

${ }^{2}$ Associate Professor, Department of Economics, Forman Christian College (A Chartered University), Lahore, Pakistan.

${ }^{3} \mathrm{PhD}$ Scholar, Putra Business School, Malaysia.

${ }^{4}$ Research Scholar, Department of Economics, Forman Christian College (A Chartered University) Lahore, Pakistan.

Corresponding author's Email: babar.aziz@gcu.edu.pk
} 
Many of the studies took the mix of developed and developing countries. Within these, most of the studies took female labor force participation as a dependent variable. In the present study, the purpose of only taking developing countries may pose a different picture as it has been found in the literature that family ties are strong in developing countries as compared to developed countries. Therefore, in this study, the impact of female and male participation in the labor market has been chosen because if females and males are categorized differently just to analyze the generalization of female employment for the whole set of sample. So, in the present study, male employment status and female employment status are used as dependent variables to find out the effects of the economic behavior of households.

Generally, family is treated as an independent variable, because it is considered that family affect women's participation in the labor market, which ultimately leads to influence the economic activity of the countries. In this context, Ngenzebuke et al. (2018) identified that education is an important variable for decision making in a family. The study reveals that female's say over asset-related decision-making is positively associated with males' education, more than with females' education per se. Davis and Williamson (2018) highlights that the strength of family ties is associated with important economic and social outcomes, but little is known about why the strength of family ties varies across individuals. Literature reveals that in addition to family bonding; education, age, and income are some important factors that may influence the labor force participation rate.

Bielby and Bielby (1989) examines the effect of family ties on the attitude of male and female towards outside work and household work assignments. The study concludes that both men and women are equally responsible towards outside work and household work but women have to play an additional role in maintaining the balance between outside work and household assignments as compared to the males. Reher (1998) reveals that family ties, which are prevailing from day one, will continue to prevail and influence the behavior of people, which in turn affects the economic behavior of masses in different countries according to their culture and traditions.

Higgins (2003) highlights the role of education and concludes that if more people are educated then there are more chances of employment in the country and it will also help in enhancing the economic activity. Tubbs et al. (2005) highlights that family ties are stronger in low-income households as mothers give more time to their family as compared to the elites, which in turn increases their interaction and makes their bond stronger with each other. Whereas in the case of elite families, this interaction is very less and due to this, the bond among family members is not 
strong. Diaz and Dolores (2005) stated that the participation of young adults in the labor market and the decision to stay with their parents is also influenced by family ties.

Giuliano (2007) highlights that family ties vary from country to country and it has a significant impact in determining the behavior of the economic activity. Family ties have an important impact on labor market culture and economic effects are co-related with each other, so if there are no social and family policies it will bring uncertainty in the labor market. Alesina and Giuliano (2010) highlight that strong family ties play an important role to improve the gross domestic product of the country and home production.

Gemici (2011) explores the relationship among strong family ties, location migration, labor market outcomes and marital stability of the people and concludes that in strong family ties, people are less willing to migrate and would be ready to work even at a low level of wage. Lucifora and Meurs (2012) reveal that religion has a significant influence on family values. Thus, family ties have a positive effect on the preferences and welfare of individuals. Chang (2013) explores that age, education and religious affiliation play an important role to define family ties, that has the ultimate impact on the economic and social wellbeing of the family and society.

Alesina and Giuliano (2014) explore that trust and strong family ties have a negative relation with each other because people with strong family ties trust outsiders less as compared to their family members. Thus, strong family ties also show negative relation with female participation in the labor force while positively related to home production. So, it gives rise to home production. Mare et al. (2016) explore that family is an important institution and it has an imperative impact on not only social values and norms but also on the underground economy. Family structures also affect the system of taxation. Stronger family ties are directly proportional to more chances of tax evasion.

Strong family ties are important because it leads to growth, happiness and satisfaction towards life. It is observed that in a case where the family formation is knitted with strong ties, people are more linked with the family and spend on them. Therefore, decisions related to consumption and saving are affected in the presence of strong family ties, which in turn affects the demand for goods and labor market activities. Therefore, the level of the wage, employment status and level of output are affected at the macro level (Becker, 1988). Thus, the present study attempts to examine the relationship between family ties and economic activity in terms of female and male participation decisions in the labor market in developing 
economies. Furthermore, Chang (2013) and Ngenzebuke et al. (2018) highlight that female education has played a very important role, as the higher level of education has attained, it gives a sense of strength especially to females and hence they can establish themselves in the society independently. Thus, education has also been incorporated as an important variable in the study.

Principle Component Analysis (PCA) and Factor Analysis (FA) are applied to construct the index of family ties. Although both techniques give similar results but PCA illustrates a weak correlation among the variables. Therefore, FA is also applied to construct an index for family ties. More importantly, to examine the relationship between strong facility ties and economic activities, the data of sixty developing economies have been extracted from World Value Survey (WVS). Thus, present research fills the gap in the existing literature by exploring the effects of family ties, age, education and gender on the employment status of individuals in developing countries.

The remaining part of the paper is systemized as: Section 2 illustrates the research methodology and selection of the variables. In Section 3, empirical results and their interpretations are given. Section 4 spotlights the conclusion and policy recommendation.

\section{Research Methodology}

\subsection{Data}

For this study, data has been taken from World Value Survey (WVS) from the period 1981 to 2014, wave 6. Wave 7 was initiated in January 2017 and is expected to finish by January 2020. As per the plan, the online access to data was expected in July 2020. But due to COVID-19, the process has been delayed and thus we have concentrated on wave 6 . Thus wave 6 , being the biggest WVS wave conducted so far, is the most recent wave of WVS. The survey contains information on a wide variety of topics like religion, preference of people, attitudes and contains information on demographic characteristics as well. In the present study, data from 60 developing countries is used (see in appendix 1). The countries are selected on per capita Gross National Income (GNI) at current US\$ within the range of \$1005 or less to $\$ 12235$. Thus, the data used in this study covers low-income (GNI/capita is below $\$ 1005$ ); lower-middle-income (GNI/capita lies between $\$ 1,006$ to $\$ 3,955$ ); and upper-middle-income countries (GNI/capita lies between $\$ 3,955$ to $\$ 12,235){ }^{5}$

\footnotetext{
${ }^{5}$ World Bank's classifications by income level: 2017-2018 at https://blogs.worldbank.org/opendata/new-countryclassifications-income-level-2017-2018.
} 


\subsection{Methodology}

The study uses Principle Component Analysis (PCA) and Factor Analysis (FA) to construct the family ties indices. Although, the steps followed to conduct PCA or FA are almost identical, but there is a conceptual difference in using communalities. Likewise, PCA assumes that there is no error variance and the communalities are assumed to be 1 whereas for FA, error variance is assumed and communalities are not assumed to be 1 (Rourke et al. 2013). In the present study, both the techniques are applied, and both give similar results. But PCA illustrates a weak correlation among variables, so FA is being applied to construct an index for family ties. The results of FA are given in appendix 2 .

Moreover, the dependent variable is in dichotomous form, i.e., 1 is employed and 0 otherwise; therefore, the Logit model is being used. This study estimates two models in which the employment status is a dependent variable whereas family ties, age, education and income are independent variables. Model 1 illustrates "the effect of family ties on female employment status" and model 2 presents "the effects of family ties on male employment status".

Model 1: $f e s=\alpha_{0}+\alpha_{1}(f t)+\alpha_{2}($ age $)+\alpha_{3}(e d)+\alpha_{4}($ in $)+\mu_{i}$

Model 2: mes $=\beta_{0}+\beta_{1}(f t)+\beta_{2}($ age $)+\beta_{3}(e d)+\beta_{4}($ in $)+\mu_{i}$

fes $=$ female employment status

mes $=$ male employment status

$f t=$ family ties

age $=$ age of households

$e d=$ education

in $=$ income

$\mu_{i}=$ stochastic error term

The description of the variables is as follows:

Employment Status: Economic behavior of a household is taken as a dependent variable and is measured by the employment status. In this study, the role of women and men in the labor market is taken separately to see how their contribution affects economic activity as it has an imperative impact on the economy. The questions used in the survey and its answer consists of value from 1 to 7 . Here, 1 is for a full-time job, 2 is for a part-time job, 3 for self-employed, 4 is 
for retired, 5 for housewife or not working outside, 6 for student and 7 is for unemployed. Therefore, the value 1 to 3 is for the working class and 4 to 7 for individuals who are not working. So, here a dummy variable is created 1 for working and 0 for not working.

Family Ties: Family is defined as a group of people living together, connecting through blood relation they are influenced by actions of other family members and family ties provide strong relationship among family members. Different studies like Becker (1988), Bertrand and Schoar (2006), La-Ferrara (2010), Chang (2013), Alesina and Giuliano (2014) and Davis and Williamson (2018) have emphasized importance of family ties in such a way that the path of family economics shas been moved ahead from discussion of birth rate, size of family, marriage and divorce. The family ties index is constructed by using the principle axis factoring.

Age: Age is also being used as an independent variable in this study and is expressed in years. This variable is very important in such a manner that attitudes, habits and behaviour of people vary with changes in age. This variable also helps to capture the effect of family ties on the participation of people in the labor force and this fact is being explained by the researchers such as Bertrand and Schoar (2006), and Alesina and Guiliano (2013). This variable is also being used by Chang (2013) to find out "how age affects the family ties" which in turn affects the economic activity.

Education: Education is incorporated as a variable to check the influence of education on market participation and also has an important impact on the attitude of people regarding work especially for females. Bertrand and Schoar (2006), Alesina and Giuliano (2014), and Ngenzebuke et al. (2018) also took education as a variable and found that it is also playing an important role in females lives as it is developing awareness to contribute towards labor market.

Income: Income is the factor that influences the participation of all groups (male and female labor participation) and with variation in income level, the spending and participation of people are also being affected. It also affects the mobility of people and has a strong impact on male employment status as compared to female employment status. Males have more mobility as compared to females, so males have an opportunity to search for better jobs and income. Guiso et al. (2003), and Reher (1998) also used income with family ties.

Gender: The role of gender is also included in this study because gender plays a crucial role in the labor market. If employment status is taken and the results 
are generalized for both males and females then, the results may appear biased. Since the past few decades females have attained an imperative position in society.

\section{Results and Discussion}

This section presents the results, based on the estimation of the two models and shows that how family ties are affecting the female and male employment status. The results of model-1 are given in Table 1 .

Table 1: Results of Model 1: $f e s=\alpha_{0}+\alpha_{1}(f t)+\alpha_{2}($ age $)+\alpha_{3}(e d)+\alpha_{4}(i n)+\mu_{i}$

\begin{tabular}{|c|c|c|c|c|}
\hline Variables & Logistic Co-efficient & Marginal effects & Odd ratios & p-value \\
\hline Family ties & 0.0907 & 0.0211 & 1.0950 & 0.031 \\
\hline Age & -0.0047 & -0.0011 & 0.9952 & 0.000 \\
\hline Education & 0.0098 & 0.0022 & 1.0099 & 0.000 \\
\hline Income & -0.0005 & -0.0001 & 0.9994 & 0.062 \\
\hline No of Observations & 65535 & Pseudo $\mathrm{R}^{2}$ & & 0.0019 \\
\hline LR Chi $^{2}$ (18) & 166.31 & Log Likelihood & & -42769.81 \\
\hline Prob $>\mathrm{Chi}^{2}$ & 0.000 & & & \\
\hline
\end{tabular}

Source: Authors' calculations

The results highlight that family ties are positively related to employment status. Results show that one percent addition in family ties increases the probability of female participation in the labor market by about 0.021 percent. This result is in contrast to the study of Alesina and Giuliano (2014), which determines a negative relationship between family ties and female participation in the labor market. A possibility of this contrast is that study by Alesina and Giuliano (2014) includes combined data of developed and developing countries. In developed countries, family ties are weaker, whereas in developing countries family ties are stronger. Therefore, in the present study, only developing countries are considered and a positive relationship can be justified on the given grounds.

Age reflects a negative relation with female employment status. The result shows that a one percent increase in age decreases the probability of female employment by about 0.0011 percent. The results highlight that females' family responsibilities increases over time and after reaching a certain age females' participation in the labor market decreases. The results also show that in families where ties are stronger and when children are grown enough to earn, they do not want their mothers to go out for work.

Education reveals a positive relation with female employment status. It explains that if there is a percent increase in education, it leads to about $0.0022 \%$ increase in the level of female employment status. A higher level of education gives a sense of strength, especially to females. They started to get higher education, 
which helps them to establish not only independently, but also documents an important role in determining the strength of families (Chang, 2013).

A negative relationship between income and female employment status is observed. The results represent that if income increases by one percent, it leads to a 0.0005 percent decrease in the employment of the females. The results depict that in developing countries females are not encouraged to go out to work and they are considered liable only to handle household chores. In strong ties, usually, the family needs someone who keeps them together, and mostly it is done by a mother or a wife. So, females in strong ties cases are expected to assume a traditional role at home. Another reason is that in strong family ties, the household head is the only breadwinner and has the responsibility of the entire household. Consequently, less is spent on the education of females, which in turn leads to less participation in the labor market.

It is important to consider that in developing countries, the ties are strong and males are usually involved in the earning activities and have different nature of jobs. In addition, household responsibilities and time allocation for the family are also considered key liabilities of male members. Therefore, a separate model of male employment status has been employed. To show the effect of family ties on the male employment status; the results of model-2 are given in Table 2 .

Table 2: Results of Model 2: mes $=\beta_{0}+\beta_{1}(f t)+\beta_{2}($ age $)+\beta_{3}(e d)+\beta_{4}(i n)+\mu_{i}$

\begin{tabular}{|c|c|c|c|c|c|}
\hline Variables & \multicolumn{2}{|l|}{ Logistic Co-efficient } & Marginal effects & Odd ratios & p-value \\
\hline Family ties & \multicolumn{2}{|l|}{0.0602} & 0.0129 & 1.0620 & 0.322 \\
\hline Age & \multicolumn{2}{|l|}{-0.0074} & -0.0016 & 0.9925 & 0.000 \\
\hline Education & \multicolumn{2}{|l|}{0.0121} & 0.0026 & 1.0122 & 0.000 \\
\hline Income & \multicolumn{2}{|l|}{-0.0034} & -0.0007 & 0.9965 & 0.000 \\
\hline \multicolumn{2}{|c|}{ No of Observations } & 62249 & Pseudo $\mathrm{R}^{2}$ & & 0.0040 \\
\hline \multicolumn{2}{|c|}{$\mathbf{L R}_{\mathbf{C h i}} \mathbf{2}^{2}(18)$} & 313.02 & \multicolumn{2}{|c|}{ Log Likelihood } & -38947.448 \\
\hline Prob $>\mathrm{Ch}$ & & 0.000 & & & \\
\hline
\end{tabular}

Source: Authors' calculations

The results in Table 2 show that male employment status and family ties have a insignificant relationship. It implies that if family ties increase by a percent then there will be a probability of 0.0129 percent increase in the male employment. This relationship is justified in case of developing countries where male is only the bread earner whereas rest of the family is dependent on him.

Age represents a negative relation with male employment status. If age increases by one percent, it will lead to about a 0.0016 percent decrease in male employment. This implies that male employment decreases after a certain age and this may be because of retirement age. Another possibility is that after reaching a 
certain age, children also grow up and start to earn. After this, they do not want their parents to work and it mostly happens where family ties are stronger (Chang, 2013).

Education is positively related to the participation of males in the labor market. It shows that a one percent increase in education leads to an almost 0.0026 percent increase in male employment status. The results show that in developing countries males are getting a higher education and actively participating in economic activities.

Results show that a one percent increase in income decreases the probability of male employment status by about 0.0007 percent. The reason is that in strong family ties, usually, head male participates in the earning activities and is responsible to meet the financial needs of the other family members. Particularly, a high income of the family head usually restricts the participation of other family members in the earning activities. Thus, an increase in the income of household head and a high dependency rate decreases male participation in the labor market. Moreover, when a person's income is not enough, the less amount is being spent on the education of the children so less is the male participation in the labor market (Alesina and Giuliano, 2014).

The overall results show that strong family ties affect the employment status in the case of developing countries. As an institution, family ties affect females more as compared to males. In short, the results indicate that where family ties are stronger, the people are more connected to their families, and all their activities, in turn, have a strong impact on the employment status of the country. In countries where strong family ties exist, females play an important role especially mothers in keeping the family intact and also play an imperative role in transferring values from the current generation to the next generation (Mare et al. 2016).

\section{Conclusion}

Family ties play an important role in determining the economic behavior of households. The importance of family cannot be denied for the development of a society. In fact, this was not given much attention in the previous studies. Keeping in view the importance of family ties and how such ties are greatly shaped the economic behavior of households, this study analyzes data from sixty developing countries. To estimate the robust results, a binary Logit estimation technique is used and the robustness of the results is also examined. The results indicate that strong family ties affect both male and female employment status but such ties have a stronger influence on female employment status. The results highlight that age has 
a negative effect on employment status; as age increases, the capacity to work decreases. While result depicts that as the level of education increases the chances for labor market participation also increase. However, income has a negative sign, which means that if the family income is higher than females are less encouraged to work, have limited mobility and spend most of the time at home. The results from this study suggest that females show their preferences for joining the labor market in presence of stronger family ties in developing. Most importantly, females are the major chunks of the labor force in the demographic structure of developing countries. Therefore, their participation in the labor force will have a positive effect on the economy and strong family ties can play a vital role in the progress of countries. 


\section{References}

Alesina, A., \& Giuliano, P. (2010). The power of the family. Journal of Economic Growth, 15(2), 93-125.

Alesina, A., \& Giuliano, P. (2014). Family ties. In Handbook of Economic Growth, $2,177-215$.

Becker, G. S. (1988). Family economics and macro behavior. American Economic Review, 78(1), 1-13.

Bertrand, M., \& Schoar, A. (2006). The role of family in family firms. Journal of Economic Perspectives, 20(2), 73-96.

Bielby, W. T., \& Bielby, D. D. (1989). Family ties: Balancing commitments to work and family in dual earner households. American Sociological Review, 54(5), 776-789.

Chang, W. C. (2013). Family ties, living arrangement, and marital satisfaction. Journal of Happiness Studies, 14(1), 215-233.

Davis, L. S. \& Williamson, C. R., (2018). Cultural roots of family ties. Available at: $\quad$ https://ssrn.com/abstract=3274884 or http://dx.doi.org/10.2139/ssrn.3274884

Diaz, A., \& Dolores, M. (2005). Family ties and labor supply. Investigations Económicas, 29(2). 289-329.

Gemici, A. (2011). Family migration and labor market outcomes. Manuscript, New York University.

Giuliano, P. (2007). Living arrangements in Western Europe: Does cultural origin matter? Journal of the European Economic Association, 5(5), 927-952.

Guiso, L., Sapienza, P., \& Zingales, L. (2003). People's opium? Religion and economic attitudes. Journal of Monetary Economics, 50(1), 225-282.

Higgins, N. O. (2003). Trends in the youth labour market in developing and transition countries. World Bank Social Protection Discussion Paper Series, 0321 .

La-Ferrara, E. (2010). Family and kinship ties in development: An economist's perspective, In . In Platteau. J., \& Peccoud, R. (Ed.) Culture, Institutions, and Development: New Insights into an Old Debate, Routledge Studies in Development Economics: UK. 
Lucifora, C., \& Meurs, D. (2012). Family values, social needs and preferences for welfare. IZA Discussion Paper, 6977.

Mare, M., Motroni, A., \& Porcelli, F. (2016). Family ties and underground economy, MPRA Paper, 76059. Available at: https://mpra.ub.unimuenchen.de/76059/.

Ngenzebuke, R. L., De Rock, B., \& Verwimp, P. (2018). The power of the family: Kinship and intra-household decision making in rural Burundi. Review of Economics of the Household, 16(2), 323-346.

Reher, D. (1998). The history of the family in Spain: Past development, present realities, and future challenges. The History of the Family, 3(2), 125-136.

Rourke, N., Psych, R., \& Hatcher, L. (2013). A Step-by-Step Approach to Using SAS for Factor Analysis and Structural Equation Modeling (Second Edition). SAS Institute.

Tubbs, C. Y., Roy, K. M., \& Burton, L. M. (2005). Family ties: Constructing family time in low-income families. Family Process, 44(1), 77-91. 
Family Formation, Gender and Labor Force Participation Decision in Developing Countries

\section{Appendix}

Appendix 1: List of developing countries

\begin{tabular}{|c|c|c|c|c|c|}
\hline 1) & Argentina & 21) & Guatemala & 41) & Peru \\
\hline 2) & Albania & 22) & Hungry & 42) & Philippines \\
\hline 3) & Armenia & 23) & India & 43) & Romania \\
\hline 4) & Azerbaijan & 24) & Iran & 44) & Rwanda \\
\hline 5) & Algeria & 25) & Iraq & 45) & Slovenia \\
\hline 6) & Brazil & 26) & Indonesia & 46) & South Africa \\
\hline 7) & Bangladesh & 27) & Jordan & 47) & Turkey \\
\hline 8) & Belarus & 28) & Kazakhstan & 48) & Taiwan \\
\hline 9) & Bulgaria & 29) & Kyrgyzstan & 49) & Tanzania \\
\hline 10) & Chile & 30) & Lebanon & $50)$ & Thailand \\
\hline 11) & China & 31) & Lithuania & 51) & Tunisia \\
\hline 12) & Colombia & 32) & Mexico & $52)$ & Ukraine \\
\hline 13) & Croatia & 33) & Macedonia & 53) & Uruguay \\
\hline 14) & Dominican republic & 34) & Moldova & 54) & Uganda \\
\hline 15) & El Salvador & 35) & Montenegro & 55) & Uzbekistan \\
\hline 16) & Egypt & 36) & Morocco & 56) & Venezuela \\
\hline 17) & Ecuador & 37) & Mali & $57)$ & Vietnam \\
\hline 18) & Ethiopia & 38) & Malaysia & $58)$ & Yemen \\
\hline 19) & Georgia & 39) & Nigeria & 59) & Zimbabwe \\
\hline 20) & Ghana & 40) & Pakistan & $60)$ & Zambia \\
\hline
\end{tabular}


Appendix 2: Principle Axis Factoring Tables

Model 1: Female employment status

Correlation Matrix

\begin{tabular}{|c|c|c|c|c|}
\hline $\begin{array}{c}\text { Zscore: } \\
\text { Important } \\
\text { in } \\
\text { life: Family }\end{array}$ & $\begin{array}{l}\text { Zscore: } \\
\text { Respect and } \\
\text { love for } \\
\text { parents }\end{array}$ & $\begin{array}{l}\text { Zscore: Parents } \\
\text { responsibilities to } \\
\text { their children }\end{array}$ & $\begin{array}{l}\text { Zscore: Important } \\
\text { child qualities: } \\
\text { independence }\end{array}$ & $\begin{array}{c}\text { Zscore: } \\
\text { Important } \\
\text { child } \\
\text { qualities: } \\
\text { obedience }\end{array}$ \\
\hline
\end{tabular}

Zscore:

Important in life:

1.00

Family

Zscore: Respect

and love for

0.01

1.00

parents

Zscore: Parents

responsibilities to

0.03

0.69

1.00

their children

Zscore:

Important child

qualities:

0.01

0.01

0.01

1.00

independence

Zscore:

Important child

qualities:

0.01

0.05

0.06

0.06

1.00

obedience

Factor Matrix ${ }^{a}$

\begin{tabular}{lcc}
\hline & \multicolumn{2}{c}{ Factor } \\
\cline { 2 - 3 } & $\mathbf{1}$ & $\mathbf{2}$ \\
\hline Important in life: Family & 0.028 & 0.011 \\
Respect and love for parents & 0.829 & -0.026 \\
Parents responsibilities to their children & 0.833 & 0.002 \\
Important child qualities: independence & 0.014 & 0.233 \\
Important child qualities: obedience & 0.071 & 0.235 \\
\hline
\end{tabular}

Extraction Method: Principal Axis Factoring.

a. 2 factors extracted. 9 iterations required.

\section{Rotated Factor Matrix ${ }^{a}$}

\begin{tabular}{lcc}
\hline & \multicolumn{2}{c}{ Factor } \\
\cline { 2 - 3 } & 1 & 2 \\
\hline Important in life: Family & 0.027 & 0.013 \\
Respect and love for parents & 0.829 & 0.016 \\
Parents responsibilities to their children & 0.832 & 0.044 \\
Important child qualities: independence & 0.002 & 0.233 \\
Important child qualities: obedience & 0.059 & 0.239 \\
\hline
\end{tabular}

Extraction Method: Principal Axis Factoring.

Rotation Method: Varimax with Kaiser Normalization.

a. Rotation converged in 3 iterations.

Factor Transformation Matrix

\begin{tabular}{lcc}
\hline Factor & $\mathbf{1}$ & $\mathbf{2}$ \\
\hline 1 & 0.999 & 0.051 \\
2 & -0.051 & 0.999 \\
\hline
\end{tabular}

Extraction Method: Principal Axis Factoring.

Rotation Method: Varimax with Kaiser Normalization. 
Model 2: Male Employment Status

Correlation Matrix

\begin{tabular}{|c|c|c|c|c|c|c|}
\hline & & $\begin{array}{l}\text { Important } \\
\text { in life: } \\
\text { Family }\end{array}$ & $\begin{array}{l}\text { Respect } \\
\text { and } \\
\text { love for } \\
\text { parents }\end{array}$ & $\begin{array}{c}\text { Parents } \\
\text { responsibilities } \\
\text { to their } \\
\text { children } \\
\end{array}$ & $\begin{array}{c}\text { Important } \\
\text { child } \\
\text { qualities: } \\
\text { independence }\end{array}$ & Obedience \\
\hline \multirow{5}{*}{ Correlation } & $\begin{array}{l}\text { Important in } \\
\text { life: Family }\end{array}$ & 1.00 & & & & \\
\hline & $\begin{array}{l}\text { Respect and } \\
\text { love for parents }\end{array}$ & 0.041 & 1.000 & & & \\
\hline & $\begin{array}{l}\text { Parents } \\
\text { responsibilities } \\
\text { to their } \\
\text { children }\end{array}$ & 0.049 & 0.649 & 1.000 & & \\
\hline & $\begin{array}{l}\text { Important child } \\
\text { qualities: } \\
\text { independence }\end{array}$ & 0.003 & 0.011 & 0.005 & 1.000 & \\
\hline & Obedience & -0.008 & 0.006 & 0.002 & -0.193 & 1.000 \\
\hline
\end{tabular}

Factor Matrix ${ }^{a}$

\begin{tabular}{lcc}
\hline & \multicolumn{2}{c}{ Factor } \\
\cline { 2 - 3 } & $\mathbf{1}$ & $\mathbf{2}$ \\
\hline Important in life: Family & 0.056 & 0.013 \\
Respect and love for parents & 0.804 & -0.001 \\
Parents responsibilities to their children & 0.807 & -0.003 \\
Important child qualities: independence & 0.011 & 0.438 \\
Obedience & 0.004 & -0.440 \\
\hline
\end{tabular}

Extraction Method: Principal Axis Factoring.

a. 2 factors extracted. 9 iterations required.

\section{Rotated Factor Matrix ${ }^{a}$}

\begin{tabular}{lcc}
\hline & \multicolumn{2}{c}{ Factor } \\
\cline { 2 - 3 } & $\mathbf{1}$ & $\mathbf{2}$ \\
\hline Important in life: Family & 0.056 & -0.011 \\
Respect and love for parents & 0.804 & 0.025 \\
Parents responsibilities to their children & 0.806 & 0.027 \\
Important child qualities: independence & 0.024 & -0.438 \\
Obedience & -0.009 & 0.440 \\
\hline
\end{tabular}

Extraction Method: Principal Axis Factoring.

Rotation Method: Varimax with Kaiser Normalization.

a. Rotation converged in 3 iterations.

Factor Transformation Matrix

\begin{tabular}{lcc}
\hline Factor & $\mathbf{1}$ & $\mathbf{2}$ \\
\hline 1 & 1.000 & 0.030 \\
2 & 0.030 & -1.000 \\
\hline
\end{tabular}

Extraction Method: Principal Axis Factoring.

Rotation Method: Varimax with Kaiser Normalization. 